\title{
A Survey of Using YouTube as Supplementary Material with University English Language Learners in Vietnam: A Replication Study
}

\author{
Pham Minh Huy ${ }^{1}$, John R. Baker² \& Nhi Khanh Tran ${ }^{3}$ \\ ${ }^{1}$ Creative Language Center, Ton Duc Thang University, Ho Chi Minh City, Vietnam. \\ Email: tg_phamminhhuy@tdtu.edu.vn. https://orcid.org/0000-0002-7174-3392 \\ ${ }^{2}$ Faculty of Foreign Languages, Ton Duc Thang University, Ho Chi Minh City, Vietnam. \\ Email: drjohnrbaker@tdtu.edu.vn. https://orcid.org/0000-0003-3379 \\ ${ }^{3}$ Faculty of Foreign Languages, Ton Duc Thang University, Ho Chi Minh City, Vietnam. \\ Email: trankhanhnhi@tdtu.edu.vn. https://orcid.org/0000-0002-4833-8073
}

\begin{abstract}
There is a growing body of international literature that has shown positive student perceptions of using YouTube as a source of supplementary teaching and learning material. The literature further shows that YouTube use in Vietnamese educational settings is growing. However, empirical investigations in this region are lacking. As such, the question arises whether international studies' results may be generalizable to this context. However, no replication studies have been undertaken to explore this. This mixed-methods external approximate replication of the seminal work in this field (Kelsen, 2009) was conducted to address this gap. The triangulated results (descriptive statistics, inferential statistics, qualitative interpretation) demonstrated that the current study showed markedly more positive perceptions than the initial study. Following this, it is suggested that, while the initial study is historically important, generalizability may not be transferable to the current Vietnamese context. It is further suggested the current study's results are employed as a reference for this context and a starting point for future investigations and discussions. The results' relevancy to the broader Asian context and suggestions for further study are also discussed.
\end{abstract}

Keywords: YouTube, EFL, ESL, ELL, language learning, Z Generation, ICT, Replication, Kelsen, Supplementary resources

\section{Introduction}

Film and education began to develop a relationship in the late 1800s that eventually led to today's acceptance of film as an educational resource (Hatfield, 1936), and, as the $20^{\text {th }}$ century progressed and technology advanced, educators found that film could be an adjunct to almost any discipline (Maynard, 1971), to include foreign language instruction (Hendon, 1980). As film continued to be adapted to, and advanced by, technology, e.g., the Internet and its video-sharing technology, many language teachers, feeling that full-length films were too long to be viewed and discussed

This Open Access article is published under a Creative Commons Attribution Non-Commercial 4.0 International License (http://creativecommons.org/licenses/by-nc/4.0/), which permits non-commercial re-use, distribution, and reproduction in any medium, provided the original work is properly cited. For citation use the DOI. For commercial re-use, please contact editor@rupkatha.com. 
in classroom sessions, turned to the shorter resources found on commercial video-sharing platforms (Donaghy, 2019) such as YouTube.

Extant international YouTube pedagogical literature shows that YouTube is widely used, accepted by educators, and benefits language learning, but an understanding of students' perceptions is also requisite in that these provide an indicator of the effectiveness of the relationship between educational resources (e.g., YouTube) and student outcomes (Fesol et al., 2017), as students' perceptions can affect the success of educational tools as much as students are affected by them (Schunk, 1992).

Accepting that students' perceptions are an important feature to be considered in course planning, Kelsen (2009), in a landmark study, explored undergraduate English language learners' (ELLs') perceptions regarding using YouTube as a supplementary language learning resource (i.e., accompaniment to the course textbook). Following this seminal study, a moderate amount of literature has explored students' perceptions of using YouTube as a resource for English language learning (Thomas, 2004). These studies, in line with the value of perception studies literature, are especially important as they inform educators' curricula, syllabi, material selection, and pedagogic decisions.

A growing amount of research has also shown that YouTube use in developing countries' educational settings is growing. However, these explorations have made only minor mention of YouTube and thus have not fully explored students' perceptions of employing it as a supplementary educational resource. In the absence of such investigations, a concern arises. That is, educators may mistakenly accept that concepts and measures developed in one country are relevant to other countries without empirically examining such concepts and measures' crossnational applicability (Durvasula et al., 2006). To address this concern, additional explorations (replication studies) are needed to determine such investigations' results generalizability to other contexts (Plonsky, 2015) (e.g., the Vietnamese context).

\section{Literature Review}

Replicability, a fundamental concept to scientific inquiry, is the application of the same scientific question to a new context with new data collection and similar methods (National Academies of Sciences, 2019) and tied to generalizability theory (Strube, 2000) as replication is necessary to allow for the precise estimation of reliability regarding questions of consistency and dependability of measurements, e.g., whether the results of one study apply to other contexts and populations. Replication is similarly recognized as a core method by L2 research methods texts (Abbuhl, 2012), the American Psychology Association (2020), and Journal Article Reporting Standards (Appelbaum et al., 2018).

Some, Mackey and Gass (2011) pointed out, might mistakenly believe that replicating a "study - broadly speaking, repeating it to test whether the same findings are obtained - would be a waste of research time, an insult to the original team of researchers, and, in general, a step unlikely to advance the field" (p. 296). However, Mackey and Gass, continued, "nothing could be further from the truth." This is because, as Epstein (1980) explained, "There is no more fundamental requirement in science than that the replicability of findings be established" (p. 796). Following 
this, replication studies have become increasingly valued in L2 literature, often receiving high citation counts (Makel et al., 2012; Marsden et al., 2018).

\subsection{The Importance of Students' Perceptions}

Students' perceptions, the focus of this study, have been defined in several very similar ways. Madsen et al. (2017) summarized these as how students perceive the learning experience, i.e., how they learn as well as how much they learn and what factors they see as relevant or important to learning success.

This area has been widely explored, so much so that an entire field of literature is well established (Kombe et al., 2016). Topics have included, but are not limited to, student achievement (Malpass, 1953); campus housing living conditions (Ballou, 1967); university environments (Buchanan, 1989); instructors' humor (Wanzer \& Frymier, 1999); course satisfaction (Lee et al., 2011), and, more recently, a myriad of concerns regarding the many components of ICT instruction (Morris, 2017), e.g., YouTube.

In short, students' perceptions is a deeply and widely explored area as educators have come to realize that student perceptions are an important mediator in the relationship between course materials and student outcomes (Shuell, 1988).

\subsection{Empirical Investigations of ELLs' Perceptions of YouTube as a Language Learning Resource}

Since the inception of YouTube, a moderate amount of research has explored students' perceptions of using YouTube as a resource for language learning. This literature began with Kelsen's (2009) landmark study, which explored Taiwanese undergraduates' perceptions of using YouTube-based videos as a source of supplementary teaching material (i.e., accompaniment to the course textbook). Using a mixed-methods design, Kelsen explored five areas: Students' perceptions that YouTube (a) made classes more interesting, (b) was relevant to course materials, (c) was beneficial to language learning, (d) motivated students to study English in class, and (e) motivated them to use YouTube to study English out of class.

Kelsen (2009) reported that the participants found YouTube to be interesting, relevant, and beneficial but that motivation to use YouTube in class was considerably low, being that "students are willing to watch YouTube in class ..., but are less inclined to view it as anything other than 'entertainment'" (p. 12). Kelsen further reported that "there was little spillover leading to motivation to study English via YouTube video clips outside of class" (p. 13).

Since Kelsen (2009), several international explorations have furthered Kelsen's work and the literature in general. Empirical studies were found to have been undertaken in five of the fortyeight Asian countries: Bangladesh (Hasan et al., 2019; Subramaniam et al., 2013), Indonesia (Lestari, 2019; Nurdiawati, 2019; Purnamasari, 2018; Ridwan, 2017; Riyanti \& Marwoto, 2019; Silviyanti, 2014; Sunisah, 2019; Wahyuningsih \& Dewi, 2019), Iraq (Almoswai \& Rashid, 2017), Saudi Arabia (Aifan, 2015; Alkathiri, 2019; Gamlo, 2019), and Turkey (Balbay \& Kilis, 2017; Durgungoz, 2018), albeit these investigations have used a variety of methods and reported incongruent results. There has also been a limited amount of students' perceptions research in the Vietnamese context. However, these investigations have mainly focused on other areas (e.g., 
ICT usage), making only limited reference to YouTube (Carroll, 2017; Dinh, 2018; Duong \& Sephoo, 2014; Huynh \& Nguyen, 2019; Ngo, 2017; Pham \& Nguyen, 2019).

\subsection{Gap in the Literature}

A growing body of international YouTube students' perception literature has explored using YouTube videos as a source of supplementary teaching and learning material. Regional literature also shows that YouTube use in Vietnamese educational settings is growing. However, investigations of students' perceptions of YouTube as a supplementary resource are lacking in the Vietnamese context. As such, the question of whether international studies' results may be generalizable to the Vietnamese context arises. However, no replication studies have explored this. To address this gap, this study replicated the seminal work in this field (Kelsen, 2009) to determine if its findings regarding student perceptions of implementing YouTube-based videos as supplementary material for teaching and learning English are generalizable to the Vietnamese context.

\section{Methods}

To perform a replication of Kelsen (2009), an external approximate replication was undertaken (Appelbaum et al., 2018). To accomplish this, Kelsen's mixed-methods, single group methodology, survey instrument, and data analyses procedures were adapted. Qualitative semi-structured interviews were also employed to add further breadth and scope to the results. After which, the results of the two studies were compared using descriptive and inferential statistics and qualitative interpretation.

In keeping with APA 7 (2020) approximate replication guidelines, detailed comparisons between the original and current study are given to allow a determination if differences in outcomes ... were due to differences in participants, conditions, measures, methods of analysis, or other factors" (Appelbaum, 2018, p. 16), and, accepting that additional "measures, and/or dataanalysis methods can be used" (APA 2020, p. 69), additions are explained.

\subsection{Description of the Setting}

The study was conducted in EFL classes for non-English majors at Ton Duc Thang University's (TDTU) Creative Language Center (CLC) in Ho Chi Minh City, where requisite instruction is given to all of TDTU's 15,000 students except for English majors. The setting is similar to Kelsen's (2009) in that it was conducted with non-English majors in a university setting but different with regard to location (Vietnam, Taiwan).

\subsection{Research Question}

This study explored one research question: Are Kelsen's (2009) results regarding students' perceptions of implementing YouTube-based videos as a source of supplementary teaching material (i.e., accompaniment to the course textbook) for TESOL generalizable to the current context (Vietnam)? To explore this, five questions were adapted from Kelsen:

Q 1 Do the students perceive that using YouTube material in classes made classes more interesting? 
5 A Survey of Using YouTube as Supplementary Material with University English Language Learners in Vietnam: A Replication Study

Q 2 Do the students perceive that the YouTube material used in classes was relevant to course materials?

Q 3 Do the students perceive that using YouTube in classes was beneficial to language learning?

Q 4 Do the students perceive that using YouTube in classes motivated them to study English in classes?

Q 5 Do the students perceive that using YouTube in classes motivated them to use YouTube to study English outside of classes?

\subsection{Research Design}

To collect and analyze the data needed to answer the five questions, a five-step research design was employed. This is illustrated in Figure 3.1 and explicated in the following sections.

Figure 3.1

Research Design

\begin{tabular}{|c|c|c|c|c|}
\hline Step 1 & Step 2 & Step 3 & Step 4 & Step 5 \\
\hline$\rightarrow$ & $\rightarrow$ & $\rightarrow$ & $\rightarrow$ & \\
\hline $\begin{array}{l}\text { Pre-course } \\
\text { Questionnair } \\
\text { e }\end{array}$ & $\begin{array}{l}\text { Use of } \\
\text { YouTube } \\
\text { Videos in } \\
\text { Class }\end{array}$ & $\begin{array}{l}\text { Post-course } \\
\text { Questionnair } \\
\text { e }\end{array}$ & $\begin{array}{l}\text { Follow-up } \\
\text { Interviews }\end{array}$ & $\begin{array}{l}\text { Comparing } \\
\text { the Results } \\
\text { of the } \\
\text { Current } \\
\text { Study with } \\
\text { Kelsen's } \\
\text { (2009) } \\
\text { Findings }\end{array}$ \\
\hline
\end{tabular}

\subsection{Step 1: Pre-course Questionnaire}

The first step of the study was a pre-course questionnaire. In accordance with Kelsen (2009), the questionnaire explored students' demographics. It also queried students' computer access to determine if the potential participants were eligible for the study. Additional questions regarding language levels were added to assist with choosing appropriate level videos, albeit these data were not included in the comparison of the two studies. Three of Kelsen's questions that were not directly related to student perceptions were also excluded.

Other divergences included translating the questionnaire into the students' L1 (Vietnamese) via a back-translation procedure (Mandal, 2018) and reviewing it with bilingual TESOL instructors $(\mathrm{N}=2)$ and students $(\mathrm{N}=10)$ to identify language, meaning, and administration difficulties (Thomas, 2004) whereas these procedures were absent in Kelsen (2009). 
The survey was then administered with an online platform as (a) the population in this study (College-aged Generation Z) has been found to be comfortable with technology (Seemiller $\&$ Grace, 2016) and (b) online administration increases usable responses and aids in data analysis (Thomas, 2004) whereas Kelsen studied Generation Y and used a paper-and-pencil instrument.

\subsubsection{Description of the Participants}

The participants for the questionnaire were, like Kelsen (2009), chosen via a convenience sample of non-English majors: Three intact classes $(N=62)$ (male, 13; female, 49; $M$ age, 19.45 years, range 18 -21) with low to intermediate language levels whereas Kelsen worked with two classes (usable responses, $\mathrm{N}=62$ ) (male, 50; female, 12; ages; language levels were not reported). Other differences included nationality (Vietnamese/Taiwanese), L1 (Vietnamese, Mandarin), and majors (multiple majors/no mention of disciplines offered). No incentives for participation were given in either study.

\subsection{Step 2: Use of YouTube Videos in Class}

As with Kelsen (2009), step two introduced YouTube videos in conjunction with the course textbook (i.e., YouTube video clips were shown during class sessions and students participated in video-related activities). In keeping with approximate replication, this was a slight variation from Kelsen's text, i.e., a different textbook was used (Empower B1, Doff et al., 2015/World Link: Developing English Fluency, Stempleski \& Tomalin, 2005, respectively).

\subsection{Step 3: Post-course Questionnaire}

At the end of the semester, like Kelsen (2009), a post-course questionnaire was administered, which included the pre-course question (i.e., regarding computer access to determine participants' continued eligibility) and five additional 5-Point Likert questions specific to the research questions as well as open-ended questions to help provide insight into the students' perceptions.

To analyze the data collected from the respondents, the data were separated into two categories: closed and open-ended. To analyze the quantitative data from each closed survey question, in keeping with APA 7 (2020) replication guidelines, the "same analytic methods (statistical or other quantitative manipulations) used in the original study" (p. 62) were adopted: descriptive statistics (M, SD). Regarding analyzing the qualitative responses to the open-ended questions, as with Kelsen (2009), a combination of paraphrases and verbatim citations were explored. However, as there were abundant responses, emergent category analysis and debate procedures were employed, and the resulting themes were grouped relevant to each research question and presented in table form (Miles \& Huberman, 1994).

\subsection{Step 4: Follow-up Semi-structured Interviews}

While Kelsen (2009) did not include follow-up semi-structured interviews, this study, in the interest of adding further scope and breadth to the results of the open-ended questionnaire (Cresswell, 2017), did. Considering sample size saturation for homogeneous populations and purposive samples (3-10, Creswell, 2013; $10+3$, Francis et al., 2010; $15 \pm 10$, Kvale, 1996), a cluster sample was selected and given consent forms and pseudonyms ( $N=14)$ : males, 2, M aged 21; females, 11; $M$ age 19.7 years, range 18-21; and one informant who identified as other, aged 20. No purposeful intent was undertaken to regulate the sampling procedure (e.g., gender, age, major, 
7 A Survey of Using YouTube as Supplementary Material with University English Language Learners in Vietnam: A Replication Study

language ability). To avoid language difficulties, the interviews were administered in the students' L1 (Vietnamese). Afterward, the data were transcribed and member checked, emergent category analysis and debate procedures (Erlandson et al., 1993) were conducted, and the results were placed in tables (Miles \& Huberman, 1994)

\section{Step 5: Comparing the Results of the Current Study with Kelsen's (2009) Findings}

Comparing the results of the two studies, the final step in the replication showed that the means for the current study are consistently higher for each of the five questions (Table 4.1). For instance, the results showed that the current study had a mean above 4 for all five question areas, demonstrating agree to strongly agree, whereas Kelsen (2009) had only a mean 3 to 4 for the first three questions and a mean of less than 3 for questions 4 and 5, indicating less than agree for the areas of "using YouTube in class motivated you to study English in class" and "using YouTube in class motivated you to use it to study English outside of class."

Table 4.1

Comparison of the Results of Kelsen (2009) with the Current Study

\begin{tabular}{|c|c|c|c|c|}
\hline & \multicolumn{2}{|c|}{ Current Study } & \multicolumn{2}{|c|}{ Kelsen (2009) } \\
\hline & $M$ & SD & M & SD \\
\hline $\begin{array}{l}\text { 1. Using YouTube material made the class more } \\
\text { interesting. }\end{array}$ & 4.5 & .65 & 3.92 & 0.75 \\
\hline $\begin{array}{l}\text { 2. The YouTube material used was relevant to what was } \\
\text { studied in class. }\end{array}$ & 4.27 & .73 & 3.15 & .83 \\
\hline $\begin{array}{l}\text { 3. Using YouTube in class has been beneficial to your } \\
\text { English }\end{array}$ & 4.45 & .72 & 3.82 & 0.93 \\
\hline $\begin{array}{l}\text { 4. Using YouTube in class motivated you to study } \\
\text { English in class? }\end{array}$ & 4.35 & .73 & 2.95 & 1.17 \\
\hline $\begin{array}{l}\text { 5. Using YouTube in class motivated you to use it to } \\
\text { study English outside of class? }\end{array}$ & 4.26 & .83 & 2.53 & 1.04 \\
\hline
\end{tabular}

To explore this comparison further, the computed average for the current study ( $M=4.37$, $S D=.11)$ was found to be greater than the original study $(M=3.27, S D=.59)$, indicating that the respondents in the current study had markedly more positive responses to the statements used in the questionnaire than those in Kelsen's (2009) study (Table 4.2). 
Table 4.2

Group Statistics

\begin{tabular}{llll}
\hline Study & M & SD & Std. Error Mean \\
\hline Kelsen (2009) & 3.27 & 0.59 & .263 \\
\hline Current Study & 4.37 & 0.11 & .047 \\
\hline
\end{tabular}

To investigate the significance of the difference of means, an independent $t$-test was applied. Examining the results, Levene's Test for Equality of Variance indicated significance $(F=$ $11.661, p=0.009)$; hence, equal variance was not assumed. The results, therefore, indicated that there is a significant difference between Kelsen's (2009) quantitative findings and those of the current study $(\mathrm{t}(8)=-4.077, \mathrm{p}=.013)($ Table 4.3).

Table 4.3

Independent t-test

\begin{tabular}{llllll}
\hline & $\begin{array}{l}\text { Levene's Test for } \\
\text { Equality } \\
\text { Variances }\end{array}$ & of & t-test for Equality of Means \\
\hline & $\mathrm{F}$ & Sig. & $\mathrm{T}$ & $\mathrm{df}$ & Sig. (2-tailed) \\
Equal variances assumed & 11.661 & 0.009 & -4.077 & 8 & 0.004 \\
Equal variances not assumed & & & -4.077 & 4.263 & 0.013 \\
\hline
\end{tabular}

To explicate the quantitative comparison further, as Kelsen (2009) included qualitative data from open-ended questions, a comparison of the two study's qualitative findings is offered. Accepting that additional "measures, and/or data-analysis methods can also be used to test whether a finding has generality beyond the particular situation studied in the initial work, but any such variations must be clearly specified" (APA 2020, p. 69), the qualitative data from the current study's open-ended questions is presented in conjunction with that gleaned from the semi-structured interviews.

The results showed that the participants in the current study provided mostly positive reports for each of the five areas, showing a rich variety of themes for each area, with several themes being repeated across question areas (Table 4.4). However, as with the quantitative findings, an examination of Kelsen's study showed less than positive results for questions 4 and 5 , i.e., no reports for question 4 (using YouTube in class motivated you to study English in class and a negative report for question 5 (using YouTube in class motivated you to use it to study English outside of class).

Table 4.4 
9 A Survey of Using YouTube as Supplementary Material with University English Language Learners in Vietnam: A Replication Study

A Comparison of the Current Study and Kelsen's (2009) Findings

\begin{tabular}{lll}
\hline Question Item & Current Study & Kelsen (2009) \\
\hline $\begin{array}{lll}\text { 1. Using YouTube material } \\
\text { made the class more }\end{array}$ & Accessibility (OeQ) (SsI) ${ }^{\text {a }}+$ & $\ldots$ \\
interesting. & Interest: Generally Interesting (OeQ) & Generally Interesting (OeQ) + \\
& $($ SsI $)+$ & $\ldots$ \\
& Novelty (OeQ)(SsI) + & Novelty (OeQ) + \\
& Variety (OeQ)(SsI) + & $\ldots$ \\
\hline
\end{tabular}

2. The YouTube material used was relevant to what was studied in class.

3. Using YouTube in class has been beneficial to your English
Accessibility $(\mathrm{OeQ})^{a}$

General Relevancy (OeQ) (SsI) +

Skill Areas (OeQ) (SsI) ${ }^{a}+$

Accessibility $(\mathrm{OeQ})^{\mathrm{a}}+$

Affective Filter $(\mathrm{OeQ})^{\mathrm{a}}+$

Effectiveness (SsI) +

Interest $(\mathrm{OeQ})^{\star}+$

Skill Areas (OeQ) $(\mathrm{SsI})^{\mathrm{a}}+$

Accessibility $(\mathrm{OeQ})^{\mathrm{a}}+$

Affective Filter (SsI) ${ }^{\mathrm{a}}+$

Efficacy $(\mathrm{OeQ})^{\mathrm{a}}+$

Generally Motivating (OeQ) (SsI)

Identity $\quad(\mathrm{SsI})^{\mathrm{a}}+$

Interest $\quad(\mathrm{OeQ})^{\mathrm{a}}+$

Teacher Assistance (SsI) +

5. Using YouTube in class study English outside of motivated you to use it class? 4. Using YouTube in class English in class?
Efficacy (OeQ) +

Identity (OeQ) ${ }^{a}+$

Interest $\quad(\mathrm{OeQ})^{\mathrm{a}}+$

Reinforce Classroom Learning (SsI) +

Self-access (SsI) +

Skill Areas (SsI) ${ }^{a}+$ $\cdots$

Skill Areas $(\mathrm{OeQ})+$ 
Notes. OeQ = open-ended questions, Ssl = semi-structured interviews, ${ }^{*}=$ repeated across questions, $\ldots=$ not provided,$+=$ positive comment,$-=$ negative comment

Considering the quantitative and qualitative results of the current study, the findings showed that the participants demonstrated a high level of agreement that YouTube (a) made classes more interesting, (b) was relevant to course materials, (c) was beneficial to language learning, (d) motivated them to study English in class, and (e) motivated them to use YouTube to study English out of class.

Considering Kelsen's (2009) quantitative and qualitative data together for the five areas, a less positive picture emerges. It can be interpreted that the participants in Kelsen's study, as a group, found YouTube to be somewhat (a) interesting, (b) relevant, and (c) beneficial, but, (d), as Kelsen concluded, the "number of students who registered that using YouTube in class motivated them was considerably low [...], being that they regarded YouTube "more as entertainment" than for the use of studying English in the classroom, and (e) there was "little spillover leading to motivation to study English via YouTube video clips outside of class" (p. 13).

\section{Discussion}

This study performed an external approximate replication of Kelsen's (2009) investigation to determine the generalizability of Kelsen's findings to the Vietnamese context regarding students' perceptions of using YouTube-based videos as a source of supplementary teaching material (i.e., accompaniment to the course textbook) for TESOL.

The first question explored whether students perceive that using YouTube material in classes made classes more interesting. Regarding generalizability, the quantitative findings regarding interest in the current study are surprisingly generally higher than Kelsen (2009) $(\mathrm{M}=$ $4.5, \mathrm{SD}=.65 ; \mathrm{M}=3.9 .2$. SD = .75). This may be related to literature that shows higher current YouTube usage than at the time of Kelsen (VOVWorld, 2019). Related to this, Kelsen pointed to YouTube being novel at the time of his study (with the Millennial Generation), whereas the population focused on in this study (the Z Generation) has grown up with such technology, finding it to be a source to fill a variety of needs (Seemiller \& Grace, 2016). Comparing the qualitative feedback, the current study identified four themes, whereas Kelsen reported limited feedback for two features: Generally Interesting ("It lets English be more interesting") and Novelty ("It's funny to see something outside the book").

Regarding Q2, whether students perceive that the YouTube material used in class was relevant to course materials, the current study's quantitative results demonstrated that students generally found YouTube materials highly relevant $(M=4.27, S D=0.73)$. This is contrary to Kelsen (2009), who reported a much lower result $(M=3.15, S D=0.83)$ and attributed this to "students are willing to watch YouTube as stimulus in class, but are less inclined to view it as anything other than entertainment" (p. 11). Comparing the qualitative results of the two studies, three themes were found for relevancy in the current study (Accessibility, General Relevancy, Skill Areas), whereas Kelsen only reported a minor comment regarding Skill Areas, speaking (e.g., authentic language support). 
Regarding Q3, whether students perceive that using YouTube in classes was beneficial to language learning, this study's quantitative findings regarding YouTube being beneficial are considerably higher than Kelsen (2009) $(M=4.45, S D=0.72 ; M=3.82, S D=0.93)$. Comparing the qualitative feedback, the current study identified five themes (Accessibility, Affective Filter, Effectiveness, Interest, and Skill), whereas Kelsen reported limited feedback for the area of Skill Areas: i.e., one student reported: "I can learn more authentic English."

Examining the results of Q4, whether students perceive that using YouTube in class motivated them to study English in class and generalizability, the quantitative findings that YouTube being perceived as motivating students to study English in class were considerably higher than Kelsen's (2009) results $(M=4.35, S D=0.73 ; M=2.95, S D=1.17$ ). Comparing the qualitative feedback, the current study found several themes, each of which provided further breadth to the quantitative findings that YouTube motivates students to study English in class: (a) Accessibility, (b) Affective Filter, (c) Generally Motivating, (d) Identity, (e) Interest, (f) Efficacy, and (g) Teacher Assistance. However, Kelsen (2009) offered only a minor reference to Identity, concluding that the students could "relate to the authentic pop culture nature of the material and readily identify with this" (p. 12).

The results for the final question, Q5, regarding whether students perceive that using YouTube in classes motivated them to use YouTube to study English outside of class, the quantitative findings were very positive $(M=4.26, S D=0.83)$, agree to strongly agree, whereas Kelsen's (2009) results were much less so $(M=2.53$; $S D=1.04)$ (disagree to neither agree nor disagree). Comparing the qualitative feedback, it was found that the current study provided much more in-depth themes (Identity, Interest, Efficacy, Review Course Topics, Skill Areas, Self-access), all of which the students reported to motivate them to autonomously use YouTube to study English outside of class. However, Kelsen conversely pointed to a problem with self-access. That is, students were unfamiliar with YouTube: "I don't know how to use it", and "I don't know what to find." This, as with Q1, may be attributable to the differences in generations under study ( $Z$ Generation, Millennial Generation). Kelsen also offered a less than positive conclusion regarding using YouTube in class motivating students to use YouTube to study English outside of class. Kelsen claimed that in the absence of extrinsic motivators (e.g., teacher-directed assignments), students were "unwilling to use YouTube for anything other than entertainment" (p. 12).

\section{Results}

Taken together, the results of the current study demonstrated a high level of agreement among the participants that YouTube (a) made classes more interesting, (b) was relevant to course materials, (c) was beneficial to language learning, (d) motivated students to study English in class, and (e) motivated them to use YouTube to study English out of class.

These findings, as evidenced by the results of the independent $t$-test,

are significantly higher than those of Kelsen (2009) as Kelsen's participants demonstrated a lower level of "somewhat" agreement that YouTube made classes (a) interesting, (b) relevant, and (c) beneficial. Moreover, Kelsen concluded that the students showed a low level of perceptions that 
using YouTube in class (d) motivated them to study English in class and (e) a negative perception that YouTube motivated them to study English outside of class.

The interpretation of the qualitative data provided by the two studies' questionnaires as well as the additional semi-structured follow-up interviews supportively added scope and breadth to the quantitative comparison, showing that the current study's participants had more positive perceptions in each of the five areas than those of Kelsen (2009).

Considering the comparison of the two studies, it can be concluded that the current study's participants demonstrated markedly more positive perceptions in each of the five areas than the initial study. Following this, it is suggested that Kelsen's (2009) findings regarding student perceptions of using YouTube-based videos as a source of supplementary teaching material (i.e., accompaniment to the course textbook) for TESOL, while historically valuable, are not generalizable to the current context and that the results of the current study be considered as a reference for this context.

\section{Suggestions for Future Study}

The findings this study provided are certainly worthwhile as the results can practically and theoretically inform instructors and administrators with an understanding of Vietnamese undergraduate ELLs' perceptions of using YouTube as a supplementary resource for language learning (i.e., accompaniment to the course textbook), but the findings raise additional questions which merit further investigation.

This study's respondents were diverse in terms of age and major. However, they were predominately female and had beginner to intermediate levels of English. While demographic makeup was not the result of any purposeful intent of the sampling procedure, further study is needed with populations underrepresented in this study (gender, language level). The study also found high Internet and YouTube use in a Vietnamese urban context (Ho Chi Minh City). However, further explorations of Internet access, YouTube usage rates, and perceptions in Vietnam's rural areas are needed.

The results further demonstrated that students perceived that YouTube (a) made classes more interesting, (b) was relevant to course materials, (c) was beneficial to language learning, (d) motivated them to study English in class as well as (e) out of class. The results for each area were remarkably positive. However, further study is needed to explore what factors lead to the minority of negative responses in order to provide a more inclusive learning environment for all students.

Returning to the impetus for this study, replication, two additional suggestions for future study are offered. First, while these results are informative, unwarranted generalization should be avoided as this study was done at only one institution and only at one type of institution in the Vietnamese context. Thus, further studies are needed in other settings (e.g., elementary, junior high schools, high schools, technical colleges). In line with the impetus of replication, a broader potential focus also presents itself. As this study was conducted in one type of institution (university) in one geographical setting (Vietnam), it may not be representative of other ELL populations in other types of institutions, and therefore similar examinations (replications of this study) might be conducted to explore the experiences of other populations around the world. To 
further the aim of such replication, this study has purposively provided detailed methodology and results sections in the hopes of providing a starting point for replication studies and further discussions of students' perceptions of using YouTube as a supplementary resource for language learning.

\section{Acknowledgments}

We would like to thank the Editor in Chief Tirtha Prasad Mukhopadhyay and reviewers of the Rupathka Journal for their suggestions and guidance, Saqib Sohail for his contributions as a statistical analyst, Stewart Clarke for his editing suggestions, Katherine Kurowski for her APA reference suggestions, and all those who participated in the study.

\section{Funding}

This paper was funded by Ton Duc Thang University (TDTU), Ho Chi Minh City, Vietnam. Questions regarding this research can be sent to Dr. John R. Baker, Ton Duc Thang University, 19 Nguyen Huu Tho St, Tan Phong Ward, Dist. 7, Ho Chi Minh City, Vietnam. Email: drjohnrbaker@tdtu.edu.vn

\section{REFERENCES}

Abbuhl, R. (2012). Why, when, and how to replicate research. In A. Mackey \& S. M. Gass (Eds.). Research methods in second language acquisition (pp. 296-312). Wiley-Blackwell Publishing. https://rb.gy/rdsvkp.

Aifan, H. A. (2015). Saudi students' attitudes toward using social media to support learning [Unpublished doctoral dissertation]. University of Kansas. https://rb.gy/qmcxuv

Alkathiri, L. A. (2019). Students' perspectives towards using Youtube in improving EFL learners' motivation to speak. Journal of Education and Culture Studies, 3(1), 12-30. https://rb.gy/i3w5os

Almoswai, F. R., \& Rashid, B. N. (2017). The effectiveness of using YouTube video on EFL Iraqi college students' performance in grammar at Missan University. PEOPLE: International Journal of Social Sciences, 3(1), 391-402. https://rb.gy/6fxyys

American Psychological Association. (2020). Publication manual of the American Psychological Association 2020: The official guide to APA style.

Appelbaum, M., Cooper, H., Kline, R. B., Mayo-Wilson, E., Nezu, A. M., \& Rao, S. M. (2018). Journal article reporting standards for quantitative research in psychology: The APA Publications and Communications Board task force report. American Psychologist, 73(1), 3-25. https://psycnet.apa.org/doi/10.1037/amp0000389

Balbay, S., \& Kilis, S. (2017). Students' perceptions of the use of a YouTube channel specifically designed for an academic speaking skills course. Eurasian Journal of Applied Linguistics, 3(2), 235-251. https://rb.gy/nuqok6 
Carroll, M. (2017). Using CALL Materials in and out of classrooms: Student and teacher experiences. 桃山学 院大学総合研究所紀要，43(1), 237-252. https://rb.gy/3iulre

Creswell, J. W. (2013). Research design: Qualitative, quantitative, and mixed approaches. Sage.

Dinh, H. (2018). Teachers' uses and beliefs in the integration of YouTube videos into English language teaching: A comparison between ESL and EFL contexts. In J. Perren, K. B. Kelch, J. Byun, S. Cervantes, \& S. Safavi, Applications of CALL theory in ESL and EFL environments (pp. 94-110). IGI Global.

Doff, A., Thaine, C., Puchta, H., Stranks, J., Lewis-Jones, P., Godfrey, R., \& Davies, G. (2015). Empower B1+. Cambridge University Press.

Donaghy, K. (2019). Using film to teach languages in a world of screens. In C. Y. Herrero \& I. Vanderschelden (Eds.), Using film and media in the language classroom: Reflections on researchled teaching (pp. 3-18). Multilingual Matters.

Duong, T. M., \& Seepho, S. (2014). Promoting learner autonomy: A qualitative study on EFL teachers' perceptions and their teaching practices. Proceedings of the International Conference, DRAL 2 / ILA 2014, 129-137. https://rb.gy/b1ckyl

Durgungoz, A. (2018). Teachers' use of social media: Exploring implications of interpersonal relations between teachers and middle school students in Turkey. Available from ProQuest Dissertations \& Theses A\&I. (UMI No. 2116920679).

Durvasula, S., Netemeyer, R. G., Andrews, J. C., \& Lysonski, S. (2006). Examining the cross-national applicability of multi-item, multi-dimensional measures using generalizability theory. Journal of International Business Studies, 37(4), 469-483. https://rb.gy/fbyftm

Epstein, S. (1980). The stability of behavior: II. Implications for psychological research. American Psychologist, 35(9), 790-806. https://rb.gy/xxnzqk

Fesol, S. F. A., Salam, S., \& Bakar, N. (2017). An evaluation of MOOC learning based on students' perception. Journal of Multidisciplinary Engineering Science and Technology, 4(8), 7988-7992. https://rb.gy/th1e5

Francis, J. J., Johnston, M., Robertson, C., Glidewell, L., Entwistle, V., Eccles, M. P., \& Grimshaw, J. M. (2010). What is an adequate sample size? Operationalising data saturation for theory-based interview studies. Psychology and Health, 25(10), 1229-1245. https://rb.gy/emnogd

Frymier, J. R. (1960). Faculty and student perceptions of cheating. The Journal of Educational Research, 54(3), 118-120. https://rb.gy/qr08pk

Gamlo, N. H. (2019). Saudi EFL learners' perceptions of the benefits of ICT integration into English learning. Studies in English Language Teaching, 7(2), 163. https://rb.gy/rioyry

Hasan, M. M., Ibrahim, F., Mustapha, S. M., Islam, M. M., \& Al Younus, M. A. (2018). The use of YouTube videos in learning English language skills at tertiary level in Bangladesh. Infrastructure University Kuala Lumpur Research Journal, 6(1), 27-36. https://rb.gy/q98kzz

Hendon, U. S. (1980). Introducing culture in the high school foreign language class. Foreign Language Annals, 13(3), 191-199. https://rb.gy/lpmc8i

Huynh, T. L., \& Nguyen, U. N. T. (2019). Students' perceptions and design considerations of flipped interpreting classroom. Theory and Practice in Language Studies, 9(9), 1100-1110.

https://rb.gy/csdtcf 
Kelsen, B. (2009). Teaching EFL to the iGeneration: A survey of using YouTube as supplementary material with college EFL students in Taiwan. Call-EJ Online, 10(2), 1-18. https://rb.gy/cvjlqo

Kvale, S. (1996). Interviews: An introduction to qualitative research interviewing. Sage.

Lee, K. W., Yau, J. X. R., Said, N., Yoon, S. J., Tan, C. K., Nguyen, L. V., \& Thang, S. M. (2016). Designing a collaborative Malaysian-Vietnamese online writing project: A design-based research. In J. Luaran, J. Sardi, A. Aziz, \& N. Alias (Eds.), Envisioning the future of online learning (pp. 53-67). Springer. https://rb.gy/tfplnt

Lestari, N. (2019). Improving the speaking skill by vlog (video blog) as learning media: The EFL students' perspective. International Journal of Academic Research in Business and Social Sciences, 91), 915-925. http://bitly.ws/9RuF

Makel, M. C., Plucker, J. A., \& Hegarty, B. (2012). Replications in psychology research: How often do they really occur? Perspectives on Psychological Science, 76), 537542. https://doi.org/10.1177/1745691612460688

Mackey, A., \& Gass, S. M. (2015). Second language research: Methodology and design. Routledge.

Mandal, P. C. (2018). Translation in qualitative studies: Evaluation criteria and equivalence. The Qualitative Report, 23(10), 2529-2537. https://rb.gy/wfkqck

Marsden, E., Morgan-Short, K., Thompson, S., \& Abugaber, D. (2018). Replication in second language research: Narrative and systematic reviews and recommendations for the field. Language Learning, 68(2), 321-391. https://doi.org/10.1111/lang.12286

Maynard, R. A. (1971). The celluloid curriculum: How to use movies in the classroom. Hayden Book Company. https://rb.gy/ne3vx9

Miles, M. B, \& Huberman, M. A. (1994). Qualitative data analysis. Sage.

Ngo, H. T. (2017). Information and communication technologies in learning English as a foreign language (EFL): Attitudes of EFL learners in Vietnam [Unpublished doctoral dissertation]. University of Hawaii. http://bitly.ws/9RE2

Nguyen, V. M. (2019). Enhancing positive effects for the communicative + language teaching activities in English classrooms. Education Science, 16(8), 216-226. http://bitly.ws/9REt

Nurdiawati, D. (2019). YouTube animated movies as an alternative media to enhance students' listening skills. English Focus: Journal of English Language Education, 2(2), 121-131. http://bitly.ws/9REB

Plonsky, L. (2015). Quantitative considerations for improving replicability in CALL and applied linguistics. CALICO Journal, 32(2), 232-244. http://bitly.ws/9REI

Purnamasari, A. (2018). What EFL learners say about YouTube use to improve pronunciation in a blended learning environment. Journal of English Teaching, 4(3), 205-215. http://bitly.ws/9REJ

Ridwan, A. (2017). Students' perceptions toward Madura local art-based YouTube videos in speaking class. Proceedings of the 9th National English Language Teachers and Lecturers Conference. http://repo.stkippgri-bkl.ac.id/

Riyanti, G. A., Hartono, H., \& Marwoto, P. (2019). Enhancing independence and learning motivation by using YouTube. Physics Communication, 3(2), 86-93. http://bitly.ws/9RET

Schunk, D. H. (1992). Theory and research on student perceptions in the classroom. In D. Schunk \& J. Meece (Eds.), Student perceptions in the classroom (pp. 3-24). Lawrence Erlbaum. 
Seemiller, C., \& Grace, M. (2016). Generation Z goes to college. John Wiley \& Sons.

Shuell, T. J. (1988). The role of the student in learning from instruction. Contemporary Educational Psychology, 13(3), 276-295. https://rb.gy/8aylqn

Stempleski, S., \& Tomalin, B. (1990). Video in action: Recipes for using video in language teaching. Prentice Hall International

Strube, M. J. (2000). Reliability and generalizability theory. In L. G. Grimm \& P. R. Yarnold (Eds.), Reading and understanding MORE multivariate statistics (pp. 23-66). American Psychological Association. http://bitly.ws/9RFk

Subramaniam, G. K. J., Abdullah, F. P., \& Harun, R. N. S. R. (2013). Polytechnic students' perceptions of YouTube usage in the English oral communication classroom. International Journal of Asian Social Science, 3(9), 1962-1966. http://bitly.ws/9RFp

Sunisah, F. (2019). Students' perceptions of the use of YouTube videos for learning English at eleventh graders of SMKS Tunas Harapan Rimbo Bujang. [Unpublished master's thesis]. Universitas Jambi.

Silviyanti, T. M. (2014). Looking into EFL students' perceptions in listening by using English movie videos on YouTube. Studies in English Language and Education, 1(1), 42-58. http://bitly.ws/9RFe

Thomas, S. J. (2004). Using web and paper questionnaires for data-based decision making. Corwin Press.

VOVWorld. (2019, April 26). Vietnam among YouTube's top five global markets. https://vovworld.vn/enUS/news/vietnam-among-youtubes-top-five-global-markets-744235.vov

Wanzer, M. B., \& Frymier, A. B. (1999). The relationship between student perceptions of instructor humor and students' reports of learning. Communication Education, 48(1), 41-49. https://doi.org/10.1080/03634529909379152

Wahyuningsih, S., \& Dewi, S. (2019). Promoting speaking proficiency in broadcasting through YouTube project: Perceptions of undergraduate students. Proceedings of the Third English Language and Literature International Conference, 1-7. http://bitly.ws/9RFW

Minh-Huy Pham has worked as an EFL teacher for five years. His teaching area covers a variety of interests such as English for Communication, English for Special Purposes, English for Assessment. His research interests include Computer-assisted Language Learning and Information and Communication Tools in Teaching. Email: tg_phamminhhuy@tdtu.edu.vn. https://orcid.org/00000002-7174-3392

Corresponding author: John R. Baker's research interests include second language writing and reading, self-access and writing center administration, various literature interests, and how these come together in an interdisciplinary nature. Email: drjohnrbaker@tdtu.edu.vn. https://orcid.org/0000-0003-3379

Coauthor: Nhi Khanh Tran's research interests include pedagogy, curriculum development, and assessment. Email: trankhanhnhi@tdtu.edu.vn. https://orcid.org/0000-0002-4833-8073 